\title{
Developing a Short Character Based Film Increasing the Moral Value of Kindergarten
}

\author{
Yuyun Sriwahyuni, Mustaji, Umi Anugerah Izzati \\ Universitas Negeri Surabaya \\ Surabaya, Indonesia \\ Wahyukristanto777@gmail.com
}

\begin{abstract}
The Background of this research focuses on the effort of developing Learning Media In form of character-based film. The film is applied in order to help the character of Early Childhood education in learning process of the character. The research questions are: 1 . How is the feasibility of character the based film as learning media to increase the development of students' moral value in TK Wildani 2, Surabaya. 2. How is the effectivity of the character based film to increase the development of students' moral value in TK Wildani 2 , Surabaya. The objective of this research is developing an audiovisual media to increase the Early Childhood Character. The character-based film is as a tool for the teachers to transform the students' values of characters so that character education can be delivered and applied in daily life well. The film has some advantages, they are: 1 . The film is presented by the early childhood students'. It also has a manual book of how to apply it in the character learning. The research is conducted in ten phases as in Dick and Carey's theories of research development in Borg and Gall (2003). (1) Identify Instructional Goal, (2) Conduct Instructional Analysis, (3) Analyze Learners and Contexts, (4) Write Performance Objectives, (5) Develop Assesment Instruments, (6) Develop Instructional Strategy, (7) Develop and Select Instructional Materials, (8) Design and Conduct Formative Evaluation of Instruction. (9) Revise Instruction, (10) Design And Conduct Summative Evaluation.
\end{abstract}

Keywords-Audio-Visual Media (Video); Character based film; Moral Value

\section{INTRODUCTION}

Education in Early Childhood character is needed from the beginning because it is a foundation for children before they are to the next level, therefore children need to develop character values from childhood at home or on school. In the Development of character value in Early Childhood at school children not only use the characters learning theories contained

from textbooks but the existence of direct practice or habituation. If this habit continues to be done in everyday life will produce children who have good behavior. Yet we still see many schools in instilling character values just as the lessons taught in school are not matched by direct practice.

Currently, the more news we hear about the various kinds of character decline in this nation ranging from leaders to the community in various circles that cause unrest many people about the future of this nation. These events indicate that there is now a character problem in this nation. This is the initial idea in making the title of research, through educational characters educators can print this age children who have the character and can produce a new generation of better $d \mathrm{n}$ many areas of life.

Muklas (2012) argues that the character education of the nation is not just taught as a subject, but must be understood, familiarized, exemplified and sustainable. Character education in general is the responsibility of all, both in the family, society, and nation. Schools are part of the community that has an important role in the formation of the character of early childhood. Character education in schools can be implemented through the learning process and must be integrated in all games. All of these character values can be embedded through an educator and in order to maximize the need for a medium that will help teach about the character.

The formation of character is one's atu national education goals, in article 1 of the Law on National Education System of 2003 states that among the objectives of national education is to develop the potential of learners to have the intelligence, personality and noble spirit, from which it can be concluded that education does not only form the intelligent Indonesian people but also have personality and character, so that laterborn a generation of nations that can grow and develop with the character breathe noble values of the nation and religion.

Education aimed spawned beings intelligent and strong character, also had said to Martin Luther King (in Muchlas 201 2 ), which is intelligence plus character is the goal of true education (intelligence character is the ultimate goal of education is actually. The success of character education at this time will determine the future of the early childhood itself and the future of our nation, because in the next few years they will be the leaders in this country.

Megawangi (2010) adds that there are nine pillars of character, which are important to inculcate in the formation of the child's personality. The various pillars of character are in line with the values of local wisdom that contain noble values universal, including: (1) love to God and the universe and its contents, (2) responsibility, discipline, and independence, (3) honesty, (4) respect and courtesy, (5) compassion, care and cooperation, (6) confidence, creative, hard work, and never give up, (7) justice and leadership, (8) good and humble, (9) tolerance, peace, love and unity. 


\section{Dr. Marvin Berkowitz Marvin Berkowitz said :}

"Effective character education is not a program or set of programs to a school. Rather it is a transformation of the culture and life of the school. " " (In the journal How to Do Character Education by David H. Elkind and Freddy Sweet Ph.D 2014 ) .

"Effective character education does not add a program or a set of programs to the school but an act that will become a habit and become a culture (change person) but as a cultural transformation for school life According to the Minister of National Education Regulation number 58 of 2009 on education standards (2) familiarize yourself with worship, (3) to understand noble behavior (honest, helpful, polite, respectful, etc.), (4) distinguishing good and bad behavior, (5) recognizing rituals and religious holidays, (6) respecting the religion of others.

\section{According to Damon}

" Children's moral sensibilities are easy to overlook if we expect them to be expressed in the behavior that conforms to our adult standards Adults who would understand children's morality must understand the significance of children's acts within the context of the child's world. ( in Journal of Early Education and Development, University of Missouri, Martin $2015)$."

The moral sensitivity of children is easily directed if we do not force them to understand the desires of adults but instead, adults must enter the world of children. The tendency of adults to impose what is considered good for children. We need to remember that children also have desires that we as adults should understand and understand what they want, because what in the child's mind is not as far as what is in the mind of an adult.

Based on some of the above description can be concluded that character education is very important to be invested from an early age. If the character education is hindered delivered very precise and can directly apply in everyday life, then we will find children who have good morals that make a generation that has good moral values in running everyday habits.

We have seen the fact that children at these moments are very easily influenced by television shows, how they are hooked with gadgets that feature audio and visual images that draw their attention complete with exciting features which greatly facilitate children to see and hear many things without the knowledge of parents without going through the screening process first . If this happens gradually it will erode the value of characters that have existed in the child's self that resulted in their moral values will fall slowly.

Similarly, the number of television channels and television programs that credits less educational activities for children. This is very dangerous to their development because they are also easily stimulated by what they hear and see. Therefore, the media teaching in the form of audio and visual in the present age that is called today's child is very appropriate for them. A fun learning medium that contains the content of the causative values packaged in a short film that the children themselves are presenting teaches on how to apply moral chasing for the Early Childhood.

Children are very interested in the audio-visual media, therefore in the delivery of media exposure to the values of the characters can be taught through media Fun media learning is required in the flow of character values in children. develop a medium to teach the character with which children play an early age that can later be used in the teaching and learning process. The author chose the film media because this medium is being liked by the child. And we will not force the child, but the child will do it with pleasure. We enter the world of children, in accordance with the wishes of children.

This study focuses on efforts to develop learning media in the form of films played by early childhood, the story of the film to be played is taken from the idea of the children themselves, so that they will play the movie according to their own ideas and also by looking at the values of karate on the Regulation of the Minister of Education National number 58 of 2009 on early childhood education standards character building through early childhood movie is expected to prepare their future as human beings who have become human characters at once noble mind and character that have the vision and mission to build this nation better.

Sujiono (2009) argues religious and moral values also have an important role in the development of children who must be noticed from an early age one of them recognize the good and bad behavior. This is because early childhood is a very decisive age in the formation of character and personality of children.

\section{A. Problem Formulation}

Based on the above background, then the formulation of the problem in this study are:

1. How is the feasibility of short character-based film media to improve the development of Moral Values in children in Kindergarten 2, Surabaya?.

2. How is the effectiveness of short character-based film media to improve the development of Moral Values in children in Wildani 2, Surabaya?.

\section{B. Research Objectives}

1. Describe the feasibility of short character-based film media to improve the development of Moral Values in children in Wildani 2, Surabaya.

2. This film media can be used to improve the development of Moral Values that can be used to facilitate educators in conveying character lessons in early childhood.

3. This development research aims to produce instructional media in the form of (1) Film in VCD format (Video Compact Disk) and has passed validation test and user trial and ( 2 ) book alloy in using character film that has been made.

\section{Product Specs Expected}

The product specification is expected and resulted in the development of this research is learning in the form of media consisting of (1) the film for young children and (2) the book 
pan Duan for educators in the use of the film characters for early childhood.

1. Physical Specifications :

a. Presented in the form of VCD ( video compact disk) is very easy to operate.

b. It is accompanied by a guidebook manual that contains:

1) Title

2) Basic competencies

3) Indicator

4) Subject matter

5) Syllabus

6) Plan Implementation of Weekly Learning (RPP M)

7) Lesson Plans (RKH)

\section{Content Specification}

This learning product will be developed using Dick and Carey's development research model in Borg and Gall ( 1987: 569) which will have the following content:

a. Film short on learning the characters played by early childhood

b. Short movie impressions accompanied by the appearance of text, sound, and songs about the content of the film.

c. This video show can be displayed on gadget (HP), computer or by using VCD player.

\section{The Importance of Development}

The development of film media is very important for character learning for early childhood because the formation of good character can also bring the future of our nation much better. Some of the benefits that are expected to be obtained from the development of this media are:

1 Theoretical benefits

Theoretically, this research and development capable contribute to increasing the scientific assessment of learning in a kid it is. Primarily related to the development of early childhood character. The results of this research and development can be utilized as a reference for the development of similar teaching materials about the characters with contents of the product and cultural context.

\section{Practical Benefits}

In general, these results useful products for the development of instructional media to strengthen the resilience of culture which can character nation. For educators a kid it is, the product development of teaching materials will help educators to convey aspects of the character of early childhood in the form of a film with more ease and effective. For early childhood, this teaching materials can make it easier for children to learn the character and provide motivation to have good character in life.

\section{E. Assumption and Limitation of Development}

\section{Assumption}

Can improve the motivation of early childhood learning, this learning film is also able to overcome the limitations of the ability of educators to teach the character in early childhood. The use of these learning films can enhance the character of early childhood and also facilitate early childhood in learning about the character as well as providing motivation to have good character in life.

2. Limitations of Development

a) This learning video is limited to the story or idea of the child.

b) To view this video requires tools like Gadget, computer or VCD player and television.

\section{REVIEW OF LITERATURE}

\section{A. Learning Media}

The word media comes from the Latin word Medium which means intermediary or introduction. Media is an extension of man which enables it to influence others who are not in constant contact with him, the media of learning is as a messenger (the carries of messages) from some source channel to the receiver (the receiver of the message), Marshal McLuhan in Trianto (2009: 234).

Oemar Hamalik (2008: 123) argues that what is meant by instructional media is the tools, techniques, and methods used in order to make effective communication and interaction between educators and students in the process of education and teaching in schools.

Learning by using the media will give passion in learning, early childhood will develop according to interest and speed, direct interaction with the environment, providing stimulants and experiences that lead to the perception of a similar concept, Trianto (2009: 235). In this research development of teaching materials or learning, media that will be used will be VCD learning that contains character films.

Media learning is anything that can be used to channel the message (learning materials) so as to stimulate the attention, interest, thoughts, and feelings of learners in learning activities to achieve learning objectives and learning resources or physical vehicles containing instructional materials in the environment that can stimulate children to learn, on the other hand said that the learning media at the learning orientation stage will greatly help the effectiveness of the learning process in addition to generating motivation and interests of children Daryanto (2015).

According to Gagne and Briggs (in Arsyad, 2010) implicitly say that learning media can be through physical tools to convey content, messages, information from materials to be delivered to children, for example: books, tape recorders, tapes, videos, cameras, video recorders, movies, slides, photo images, graphics, televisions, and computers.

\section{B. Audio Media-Visual (Movies)}

According to Sells and Richey ( 2014: 21) Audio-video media is a way to deliver material or a material using electronic equipment to present audio and video messages. Media audio-visual has a good and clear ability because of its ability to display a live image and supported by the ability to issue sound, can also be watched in large sizes. Audio-visual learning(film) is defined as the production and utilization of learning materials related to learning through sight and hearing that are exclusively not necessarily dependent on the understanding of words and similar symbols. 
Learning video media is a media that presents audio and visual which contains good learning messages that contain concepts, principles, procedures, knowledge application theory to understand the understanding of a learning material. Video is a visible learning material (audiovisual) that can be used to convey messages/learning materials. It is said to be heard because the element of audio (audio) and visual / video (visible) elements can be presented together Arsyad (2011)

\section{Research Development}

Research and development of education ( R \& D ) is a process that is used to develop and certify educational products. The steps in this process are commonly known as $\mathrm{R}$ \& D cycles, consisting of an assessment of previous research results relating to the validity of the components in the product to be developed, developing it into a product, testing the designed product, and review and correct the product based on trial results. This is an indication that the product findings of the development activities undertaken have objectivity, Borg and Gall ( 200 7: 569 ).

Borg and Gall (200 $7: 569$ ) mention that " Research and Development Education is an industry-based development model in which the findings of research are used to create new product designs and to create new procedures, which will then be tested in a systematic, and improved until they find specific criteria to support the same effectiveness, quality or standard, Borg and Gall (200 7: 569).

According to Pranata (2011: 39), research development is a systematic effort to design a product and validate and test try so that the resulting end product is eligible for solving specific problems. Development research follows a cycle-by-step approach. The steps of this research or development process consist of a study of product research findings that will be developed and then used to develop the product through a field test process in accordance with the area in which the media was created.

Research development has a purpose to assess the changes that occur within a certain time. Similarly, the authors in this study to develop teaching materials or media that will be used in teaching the character will produce products such as: (a) educator manual, and (b) VCD media learning. All of which aims to assist educators in teaching and instilling character. In addition to facilitating the use of film, this development product is also useful to inspire educators to run the learning process with more innovative, fun and effective.

In this study, the authors will develop teaching materials using the development of Dick and Carey in Borg and Gall (2007: 570) because in the learning technology, the description of the procedures and development research steps of Dick and Carrey has been developed and trusted. Borg and gall (200 7 ) state that the development research procedure basically consists of two main objectives: (1) developing the product, and (2) testing the effectiveness of the product in achieving the goal.

The first objective is called a development function while the second goal is called validation. Thus, the concept of development research is more properly defined as a development effort which is also accompanied by validation efforts. In product development research ( $\mathrm{R} \& \mathrm{D}$ ), the collected data are simultaneously analyzed by qualitative descriptive technique then developed into a video media for character learning. The research development of this character learning video media will use the R \& D cycle of Dick and Carey contained in Borg and Gall (2003: 571). According to Borg and Gall (2007)Dick and Carey's model is one of the procedural models, a model that suggests that the application of Instructional design principles be tailored to the steps that must be taken in sequence.

\section{Character}

According to Hellen G. Douglas, in Muckhlas (2012: 41): Character is not inherited, One builds it daily by the way one thinks and acts, thought, action by action. Characters are not inherited, but something that is built continuously day by day through thoughts and deeds, mind by thought, action by action. Character is interpreted as a way of thinking and behaving so that each individual can live and cooperate, both within the scope of family, community, nation, and State. Individuals with good character are individuals who can make decisions and are prepared to account for any consequences of their decisions.

Dr.Marvin BerkowitzMarvin Berkowitz said:

"Effective character education is not a program or set of programs to a school. Rather it is a transformation of the culture and life of the school. " " (In the journal How to Do Character Education by David H. Elkind and Freddy Sweet Ph.D. 2014 ) .

"Effective character education does not add a program or set of programs to the school. It is a cultural transformation and a school life, that a character education is not just a program but an act that will become a habit and become a culture.

Hyunju Lee 2012 in International Journal of Science Education Journal entitled " Character and values are the essential driving forces that serve as general guides or points of reference for individuals to support decision-making and to act responsibly about global socio scientific issues"

According to Hyunju Lee, Character is an important driving force that serves as a general guide or a reference for individuals to support decision making and act responsibly. This is very important because the future in making decisions will be determined by one's character.

Character can be regarded as values of human behavior related to God Almighty, self, fellow human being, environment, and nationality embodied in thoughts, attitudes, feelings, words, and deeds based on religious norms, law, etiquette, culture, customs, and aesthetics. Character is a behavior that appears in everyday life both in attitude and in action, Mukhlas (2012: 41).

Warsono et al (2010) quotes Jack Corley and Thomas Phillip (2000) states: "Character is a person's traits and habits that enable and facilitate moral action" in accordance with the Great Indonesian Dictionary (2008) which says that the character is the psychological traits, or character that 
distinguishes one from another. This character is the unique values, both the inner and the embodied in behavior.

Character First, a nonprofit private organization that exists in the United States in one of its bulletins said that Early Childhood Education (PAUD) makes understanding the character easy. If you always do something, whether your mother is or is not there ( your is your mom or not ) is your character. (Adapted from www.characterfirst.com on May 28, 2017 )

In an Australian journal entitled "Behaviour Problems Across Home and Kindergarten in an Australian Sample" by Herrera and Little, 2005 states that

" Parents and teachers are important sources of identification of children's behavior problems".

Parents and teachers are an important source of identification of children's behavior problems. This explains the importance of the role of parents and educators to educate their children so as to prevent misbehavior of children who are contrary to the values of the characters.

So that the characters can be formulated universally as the value of living together based on pillars: peace (peace), respect (respect), cooperation (cooperation), freedom (freedom), happiness (happiness), honesty (honesty), humility (humility), compassion (love), responsibility (responsibility), simplicity (simplicity), tolerance (tolerance), and unity (unity). Characters are affected by heredity. The behavior of a child is often not far from the behavior of his father or mother. In the Javanese language, the term "Kacang ora ninggal lanjaran" (long bean trees never leave the wood or bamboo where it is wrapped and spread). Unless the environment, both the social environment and the natural environment come to form the character. According to, (Muklas 2012)around the harsh social environment the children tend to behave antisocial, hard, no mercy, hostile, and so forth. Meanwhile, in the arid, hot, and barren environment, the inhabitants tend to be violent and dare to die. Referring to the various definitions and definitions of the characters mentioned above, as well as factors that can influence the character, the character can be interpreted as the basic values that build a person, formed both because of the influence of heredity and the influence of the environment, which distinguishes it from others, and manifested in attitude and behavior in everyday life. (Muklas 2012).

According to Mounier in Koesoema (2010: 90-91) proposes two ways of interpretation, namely, first, the character as "a set of conditions that have been given for granted, or simply existed, more or less forced in us" (innate characters or given character ). Second, the character as "the level of power through an individual capable of mastering the condition. Character is a process that will "( willed ).

In line with the definition of the characters above, Ohoitmur Rataq and Korompis (2011: 11), asserted that "personal character consists of two elements of the innate character and the built characters. The innate character is a character whose heredity characterizes his personality. While the characters built is a character that develops through coaching and education systematically. According to the MoNE Language Center in Kemendiknas (2010: 12), the character is defined as "innate, heart, soul, personality, character, behavior, personality, nature, character, temperament, character." Character means "Personality and character ".

A person of good character or superior character is someone who tries to do the best for God, himself, his neighbor and his environment by optimizing his potential and accompanied by his awareness, emotions, and motivation. Tadkiroatun Musfiroh in Kemendiknas (2010: 12 ) argues that "character refers to a series of attitudes, behaviors, motivations, and skills". Characters relate to individual psychological characteristics. This is confirmed by Marvin W. Berkowitz (2012: 69) as follows:

" Character as an individual's set of psychological characteristics that affect the person's ability and inclination to function morally. Simply put, the character is comprised of those characteristics that lead person to do the right thing or not to do the right thing "

"Character is a collection of individual psychological characteristics that affect a person's talent and tendency to act according to morality. In other words, the character consists of the characteristics that lead someone to do something good or do something that is not good "Human character is not only born but developed. Character is developed through the process of introducing "value of life" and culture through three main institutions, namely (1) family; (2) educational institutions and (3) communities. These three institutions will be responsible for the formation of character. Character is a marker of who we really are, how we think and behave.

According to Lickona (2011), there are several important characters in our lives: responsibility, honesty, respect for others, fair dealing, cooperation, tolerance, and others. For the Indonesian nation consisting of multicultural and multireligion, then the character "respect for others" will be very important. The character of "respect for others" is necessary to possess as a basis for the behavior and attitude of the Indonesian nation.

The Law of National Education System Number 20 of 2003 which states that the vision of Indonesian education is: National education function to develop the ability and form the character and civilization of dignified nation in order to educate the nation's life, aiming for the development of potential learners in order to become a human being who believes and cautious to God Almighty, having noble character, healthy, knowledgeable, capable, creative, independent, and being a democratic and responsible citizen . ( National Education System Act: 2003 ). With the legal basis, the school is deemed necessary to develop an educational model that can lead to a characteristic graduate, the educational model that is able to realize the vision and objectives of Indonesia's education.

According to Lickona (2008) children will be able to develop an understanding of the characters, by studying and discussing the characters, observing the behavior of models that have a positive character and solve problems that have high moral and character content. When children are trying to learn to have a character of respect for others, children need to 


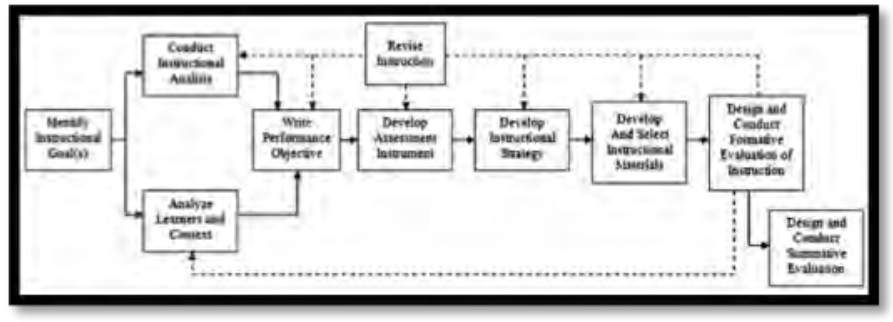

be able to have models that clearly show respect for others. Then also followed by training the characters in real activity.

\section{RESEARCH METHODS}

\section{A. Development Model}

The method is used in this study is the research and development that follows the model of the development model of Dick and Carey. Dick and Carey's model in Borg and Gall (2007: 570) suggests that instructional design according to the Dick and Carey model approach system has several components to be skipped in the development and planning process. The steps are shown in Figure 3 .1 following:

Figure 3 .1 Development Model Dick and Carey, the Borg and Gall (2007: 570)

\section{B. Development Procedure}

This Development Research was conducted for 1 year in Surabaya. The full research chart in phasing as follows:

\section{Rearch Sites}

This Development Research was conducted at TK Wildani 2, Surabaya. The study was conducted on TK A and K kindergarten students. Total students as much as 56 students.

\section{Data Analysis Technique}

1. Qualitative Descriptive

The data analysis technique used to process the data from the questionnaire obtained in the early stages to find out the needs of the community will be used qualitative descriptive analysis. Then we will see the problems and needs of today's society about character learning. Qualitative descriptive analysis is also used to process data from the review of experts This data analysis technique is used by grouping information from qualitative data in the form of responses, criticisms or suggestions of improvements contained in the questionnaire to revise the products that have been made.

\section{Quantitative}

In quantitative research, writers will use Instruments to collect data and data obtained from media experts and material experts through questionnaires will be processed by using Guttman scale, According Sugiyono (2012: 96) Guttman Scale will give a firm answer, which is "yes-no"; "True False"; "Never-never", "positive-negative" and others. On the Guttman scale, there are only two intervals of "agree" and "disagree". Research with Guttman scale is only done if you want to get a firm answer to a question that is asked. The results of this questionnaire will later provide changes in the products made so that the better. In the individual group test data, small and large groups, data analysis techniques on this trial were analyzed using percentages by using the formula:

$$
P=\frac{f}{N} \times 100 \%
$$

Figure 3.3 Formula Percentage, Sugiyono (2009)

Information:

$\mathrm{P}$ : Figures percentage

$f$ : The frequency of each questionnaire answer

$\mathrm{N}$ : Number of frequencies / many individuals

With the following assessment criteria:

$80 \%-100 \%$ : Very good

$66 \%-79 \%$ : Good No revision

$56 \%-56 \%$ : Enough

$40 \%-55 \%$ : Les good Revision

$0 \%-39 \%$ : Not good

Furthermore, the data obtained from the test results in field trials from the control group and from the experimental group will be compared. Thus the experimental model can be illustrated as shown below:

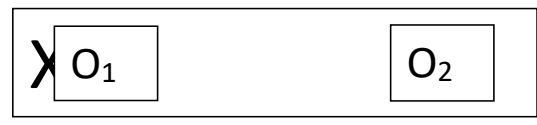

Figure 3.4 Experimental design with the control group ( Sugiyono (2012: 303))

Information

O 1: experimental group

\section{2: value of control group}

$\mathrm{X}$ : treatment for experimental and control groups

The experiments were conducted by comparing the groups using the developed media characters and control groups using the media, as usual, the book media. Students are randomly divided into two balanced groups in emotional, moral, physical, cognitive, linguistic and motor skills. Then it will be 
formed into two groups one into the experimental group (O 1) and the other group into the control group (O 2).

The experimental group $\mathrm{n}$ will be treated by using the new stem, learning using short film media and control group using the old system. Furthermore, it will be seen whether early childhood will experience improvement with new media. When the $\mathrm{O} 2$ value is significantly higher than $\mathrm{O} 1$, then the new system (character learning with audiovisual media) is more effective and efficient than using the old working system.

To verify the significance and effectiveness of the use of audio-visual media developed with non-media use, it is necessary to be tested statistically with t-tests. According to Sugiyono (2013: 138), There are two t-test formulas that can be used to test the comparative hypothesis of two independent samples. The formula is:

a. Separated Variance :

Figure 3.5 Separated Variants Variants Sugiyono (2013: 1)

b. Polled Variance:

Figure 3.6 T-test polled variance formula, Sugiyono (2013: 138)

Information :

$\mathrm{X} 1$ = average sample 1

$\mathrm{X} 2$ = average sample 2

$\mathrm{N} 1$ = sample of the experimental group

N 1 = number of control group samples

S $1=$ standard sample intersection 1

S 2 = standard sample intersection 1

S 12 = sample variance 1

S 22 = sample variance 2

$\mathrm{r}=$ Correlation between two samples

According Sugiyono (2013: 139) to select the right t-test formula then necessary considerations include:

a. Are the two averages based on two or more identical samples? b. Is the data variance of the two samples homogeneous or not. To answer it is necessary to test the homogeneity of variance

Based on the above two points, the following is given a selection to select the t-test formula:

a. If Total Project a sample $=$ n 2 and homogenous varians $(\alpha$ $12=\alpha 22$ ), a tm hen un can use formula - test both separated variance and polled variance to find out ta he t-tabe le then use $\mathrm{dk}=\mathrm{n} 1+\mathrm{n} 2-2$.

b. However, if $11 \neq \mathrm{n} 2$ and homogeneous variang ce $(\alpha 12=\alpha$ 2 2) p can be uu sed the t-test $g$ formula with polled variance. The magnitude of $\mathrm{dk}=\mathrm{n} 1+\mathrm{n} 2-2$.

c. If $\mathrm{nl}=\mathrm{n} 2$ and a not homogeneous note variant $(\alpha 12 \neq \alpha 2$ 2), a the $\mathrm{n}$ foru mula $\mathrm{t}$ - test e can be used with polled varias or

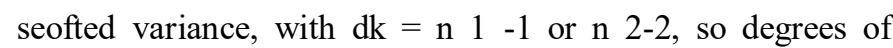
freedom ( df) a not n 1 - n 2 - 2 (Phopan in Sugiyono: 2013).

d. When $\mathrm{nl} \neq \mathrm{n} 2$ and the variance are ns ot homogeneous $(\alpha 1$ $2 \neq \alpha 22$ ), for use is a standard formula $d$ variance, the prs ice of $t$ is a substi tute for price $t$ table calculated from the difference in the price of $\mathrm{t}$ table with $\mathrm{dk}=\mathrm{n} 1-1$ and $\mathrm{dk}=\mathrm{n} 2$ 1 , divided by two then added to the smallest $t$ price.

e. When $\mathrm{nl} \neq \mathrm{n} 2$ and the variance are not homogeneous $(\alpha 12$

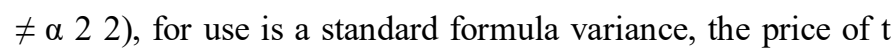
is a substitute for price $t$ table calculated from the difference in the price of $\mathrm{t}$ table with $\mathrm{dk}=\mathrm{n} 1-1$ and $\mathrm{dk}=\mathrm{n} 2-1$, divided by two then added to the smallest $t$ price.

\section{Hypothesis Formulation}

Ha: There are differences in learning outcomes between experiment and control class, experimental class using film media and control class does not use film media in character study in accordance with the indicators contained in the Minister of National Education Regulation number 58 year 2009 about early childhood education standard in scope moral and religious development

Ho: There is no difference in learning outcomes between experiment and control class, experimental class using film media and control class does not use film media in character study in accordance with the indicators contained in the Regulation of Minister of National Education number 58 year 2009 about early childhood education standard on the scope of moral and religious development .

4. Hypothesis Testing

According Sugiyono (2012: 96) There are two kinds of descriptive hypothesis testing, that is with two tail test and one tail test. Test one side there are two kinds of right side test and 
left side test. Which type of test to use depends on the hypothetical sentence

\section{a. Test two Parties ( two-tail test )}

The two-part test is used when the null hypothesis (Ho) reads "amount" and the alternate hypothesis $(\mathrm{Ha})$ reads "not equal to " ( $\mathrm{Ho}=; \mathrm{Ha} \neq)$

Figure 3.7 Test of Two Parties (Sugiyono 2013: 97)

In testing the hypothesis using two-part test applies provisions, that if the price $t$ arithmetic, is in the acceptance zone Ho or located between the table price, then Ho accepted and Ha rejected. Thus if the count is smaller or equal to $(\leq)$ of price $t$ table then Ho accepted. Price $t$ arithmetic is the absolute price, so it is not seen $(+)$ or $(-)$ it

\section{b. Test of the Parties ( One Tail Test )}

1) Test f ihak Left

Left-hand test is used when: The null hypothesis (Ho) reads "greater or equal to $(\geq)$ " and the alternative hypothesis reads "smaller $(<)$ ", the word is greater or equal to the "least or least" synonym . The left-side test can be described as follows

Figure 3.8 Left Party Test (Sugiyono 2013: 100)

In the left side of the test apply the provisions, if the price $t$ arithmetic falls on the receiving area $\mathrm{H} 0$ greater or equal to $(\geq)$ of the table, then Ho accepted and Ha rejected

2) Right-hand test

The Fear Party Test is used when the null hypothesis (Ho) reads "smaller or equal to $(\leq)$ " and the alternate hypothesis (Ha) reads "larger $(>)$. Sentences smaller or equal to synonyms with the word "bigger"

Figure 3.9 Right Finger Test (Sugiyono 2013: 102)

In this two-party test applies provisions that, if price $t$ count smaller or dama with $(\leq)$ price $t$ table, then Ho accepted and Ha rejected.

\section{RESUlT AND DISCUSSION}

\section{A. Development of learning media in the form of characters- based films}

\section{1) Media Expert Trial Results}

The results of the questionnaire that have been validated by media experts stated that, as a medium for learning character values in early childhood, there was no revision of all variables, so that it could be said that the media was suitable for use in the media. Included in the clarity of character learning goals in video media, linkages with learning objectives in accordance with Minister of National Education Regulation No. 58 concerning PAUD, the accuracy of the video displayed, accuracy of the displayed sound, suitability of supporting sources, clarity of the video displayed, clarity of the displayed sound. see opening about the characters in the video. The final note from the media expert is the need for additional guidebooks for teacher guidance when explaining "opening" to the revised video.

2) Materi Expert Trial Results

The results of questionnaires that have been validated by learning material experts also state that, character-based film media development which as a medium of learning the value of character in early childhood shows that of all the variables there is no revision, so it can be said that the media is suitable for use in terms of learning material. Included in: material relevance with learning objectives, suitability with early childhood development stages, suitability with achievement of development, suitability with the development of indicators, suitability with the theme of learning, attracting the appearance of images, attracting the appearance of sound, attractiveness in terms of image size, attractiveness to create a sense of want to know, appropriate attractiveness for early childhood.

\section{Individual Group Trial Results}

The results of individual group questionnaires show that $95 \%$ of individual group members give a "yes" answer and 5\% give a "no" answer so that it can be said that the video media is suitable for use and submitted to a small group trial.

\section{Small Group Test Results}

The results of the small group questionnaire showed that most of the $90 \%$ of small group members gave "yes" answers and only a small percentage of $10 \%$ answered "no" so that the video media could be said to be suitable for use and continued to be tested in large groups.

\section{Large Group Trial Results}

The results of the large group questionnaire showed that most $96 \%$ of large group members gave a "yes" answer and only a small percentage of $4 \%$ answered "no" so that it could be said that the video media was suitable for use on the field to see if there was an increase in the process teaching and learning in the field of character and morals according to the indicators in the National Education Minister's Regulation 58 on morality and religion.

Based on the formulation of the first problem in CHAPTER 1 concerning the development of character-based film media for learning character and moral values in early childhood. There will be results that show the existence feasibility trial results media expert, material expert testing, individual testing, piloting a small group and large group trial.

\section{B. The use of learning media in the form of character-based film media}

Lapa test support of the experimental group and the group obtained perhitungan control by using the formula $t$ test result shows that the $\mathrm{T}$ count is smaller than the table $\mathrm{T}(0.75>$ 2.110). Thus $\mathrm{Ho}$ is rejected and $\mathrm{Ha}$ accepted. So the conclusion is there is a significant difference between the experimental class and the control class that using audiovisual learning media can improve the ability of children in the moral field in accordance with the indicator of Minister of National Education Regulation number 58. From the above 
calculations on character recognition taken from Regulation of traditional song videos accompanied by character-based film media traditional games learning media character and moral values in early childhood and classes that do not use can be concluded that the video media can improve the ability of character children in group A in TK Wildani 2, Surabaya

Based on the formulation of the second problem in $\mathrm{B}$ AB 1 about whether the use of learning media TK Wildani 2, Surabaya can develop the character and moral values of early childhood. Then the results test Field trials show the effectiveness of learning activities with the increasing ability of children in the indicators contained in the Minister of National Education Regulation 58 regarding moral and religious development, including: (1) knowing the religion adopted, (2) getting used to worship, (3) understanding behavior noble (honest, helper, polite, respectful, etc.), (4) differentiating good and bad behavior, (5) knowing rituals and religious holidays, (6) respecting the religion of others.

Learning media in the form of video TK Wildani 2, Surabaya as a medium of learning the character value of early childhood was developed to improve character and morals in early childhood by taking indicators contained in the Minister of National Education Regulation 58 specifically on moral and religious sections and specifically for groups B TK Wildani 2, Surabaya

According to the results of the field test, the use of audiovisual media in the form of video that has been developed has proven effective in improving children's ability in the character field taken from the Minister of National Education Regulation 58 between classes that use character-based film media videos as a medium of character value learning for early childhood and classes that do not use media.

The development of audio-visual media in the form of videos for early childhood which was developed in this study pays attention to the theory proposed by Hellen G. Douglas, in Muckhlas (2012: 41):Character isn't inherited, its daily One builds by the way one thinks and acts, thought, action by action. Character is not inherited, but something that is built continuously day by day through thought and action, mind afterthought, action after action. Character is defined as a typical way of thinking and behaving so that each individual can live and cooperate, both within the family, community, nation, and country. Individuals with good character are individuals who can make decisions and are ready to account for any consequences of their decisions.

The results of this study are in accordance with the opinions Hamalik (2008: 123) states that what is meant by learning media is a tool, technique, and method used in order to make effective communication and interaction between educators and students in the process of education and teaching in schools.

The process of learning with the character video is also in accordance with Trianto (2009: 235) learning using the media will provide excitement in learning, early childhood will develop according to interest and speed, direct interaction with the environment, providing stimuli and experiences that give rise to perception a similar concept.
Seel \& Richey (1994: 10) states that learning technology is conceptually defined as a theory and preoccupation in designing, developing, utilizing, managing and evaluating processes, and learning resources. Also suitable as a communication tool to make the learning process more effective. The function of the media in order to achieve educational goals.

From-theory theory it shows the importance of character for the nation and too looks importance media for success in learning activities. Therefore ulis take development research to create a media that can be used to teach characters.

This is in accordance with opini anto Dary (2010: 86) that video is a very effective medium to assist the process learning, good for learning mass, groups, and individuals. According to Daryanto (2010: 87) kat ting absorption and recall a kid of the subject matter can be increased significantly if the government The o Lehan information greater than the senses of hearing and sight.

Thus the results of this study proved that I have supported the theory of Elizabeth B. Hurlock ( in Susanto 2011: 38) which states that deep child development can be enhanced or stimulated by using audio-visual media in the form of learning videos.

In accordance with the results of the questionnaire from the media and material validators stated that this media is also appropriate and can be presented for character learning which will be in the form of a DVD. And from the results of the questionnaire, it can also be seen that this video complies with the Minister of National Education Regulation 58 of 2009 concerning moral and religious education and is appropriate to be presented to early childhood.

Hereby $\mathrm{m}$ aka can be concluded that the media learning which have been developed fit for use as a medium of learning to improve the child's ability in the field of character accordance with the Regulation of the Minister of National Education No. 58 of 2009 on standards for early childhood education, the scope of the development of morality and religion, among others: (1) knowing the religion adopted, (2) getting used to worship, (3) understanding noble behavior (honest, helper, polite, respectful, etc.), (4) distinguishing good and bad behavior, (5) knowing rituals and holidays religion, (6) respecting the religion of others.

\section{CONCLUSION}

\section{A. Conclusion}

Based on the problems, research, data, and discussions that have been obtained, audio-visual media products in the form of character-based video films as a medium of character value learning in early childhood can be concluded:

1. From the results of the study showed that the character values listed in the Minister of National Education Regulation number 58 concerning religious moral values include: (1) knowing the religion adopted, (2) getting used to worship, (3) understanding noble behavior (honest, helper, polite, respect, etc.), (4) distinguish between good and bad behavior, (5) recognize rituals and religious holidays, (6) respect the 
religion of others, can be conveyed by teachers to welleducated children .

2. The implementation of the use of Audio-Visual media in the form of video characters is very mean for children and can support the learning process that is ongoing so that the development of characters that include social and religious values according to Regulation No. 58 of National Education Minister can increase.

3. Results obtained through arithmetic T-test shows that the $\mathrm{T}$ count is smaller than the $t$ table $(0.75>2.110)$. Thus Ho is rejected and $\mathrm{Ha}$ is accepted. So the conclusion is that there is a significant difference between the experimental class and the control class that using audio-visual learning media can improve children's abilities in the field of character and morals according to indicator number 58 of the Minister of National Education Regulation.

\section{B. Suggestion}

Suggestions that can be conveyed in the development of learning media products are three categories, namely:

1. To improve the ability of children in teaching and learning activities, it is suggested that schools complete teaching aids and learning media that are more varied and innovative in accordance with competency standards.

2. In using this character video media the teacher needs to practice first and prepare some supporting tools such as: laptop or VCD player and if a large room requires a speaker.

3 . For other researchers who are willing to follow up on this research, it is recommended to conduct similar research to minimize the weaknesses of the learning tools that have been developed.

\section{REFERENCES}

[1] G. Eason, B. Noble, and I.N. Sneddon, "On certain integrals of Lipschitz-Hankel type involving products of Bessel functions," Phil. Trans. Roy. Soc. London, vol. A247, pp. 529-551, April 1955. (references)

[2] J. Clerk Maxwell, A Treatise on Electricity and Magnetism, 3rd ed., vol. 2. Oxford: Clarendon, 1892, pp.68-73.

[3] I.S. Jacobs and C.P. Bean, "Fine particles, thin films and exchange anisotropy," in Magnetism, vol. III, G.T. Rado and H. Suhl, Eds. New York: Academic, 1963, pp. 271-350.

[4] Berkowitz, Marvin. 2000, Early Character Development and Education. Journal of Early Education and Development Volume 11, Number 1. University of Missouri-St. Loius.

[5] Borg, Walter R and Meredith Damlen Gall. 2007.Educational Research: An Introduction. Longman: New York.

[6] David H. Elkind and Freddy Sweet Ph.D. 2014. How to Do Character Education. Retrieved from http://www.goodcharacter.com/Article_4.html_on June 10, 2017.

[7] Depdiknas.2009. Minister of National Education Regulation number 58. Jakarta: Ministry of National Education.

[8] Depdiknas. 2003. National Education System Act number 20. Jakarta: Ministry of National Education.

[9] Harrera, Maite and Emma Little. 2005. "Behavior Problem Across Home and Kindergarden in an Australian Sample”. Australian Journal of Education \& Developmental Psychology. Vol. 5, 2005, pp 77-90.

[10] Hyunju Lee. 2012. Developing Character and Values for Global Citizens: Analysis of pre-service science teachers' moral reasoning on socioscientific issues. International Journal of Science Education. Volume 34, 2012-Issue 6.

[11] Lickona, Thomas. 2004. The Return of Character Education. New York: Character Education.

[12] Samami, Muklas and Hariyanto. 2012. Concepts and Models of Character Education. Bandung: PT Remaja Rosdakarya.

[13] Seels, Barbara B and Richey Rita C. 2014. Instructional Technology: The Definition and Domains of the Field. Washington DC: Association of Educational Communications and Technology.

[14] Trianto. 2009. Design of Thematic Learning Development for Early Childhood. Jakarta: Kencana Prenada Media Group.

[15] Trianto. 2009. Designing Innovative-Progressive Learning Model. Jakarta: Achievement Library.

[16] Warsono et al. 2010. Character Education model at Surabaya State University. Surabaya: Universitas Negeri Surabaya. 